\title{
A SEMANTIC ANALYSIS OF DIFFERENCE LEXICAL CHOICES IN QURAN TRANSLATION OF INDONESIAN AND DUTCH VERSIONS
}

\author{
Rika Astari, Betty Mauli Rosa Bustam \\ Universitas Abmad Dablan Yogyakarta, Indonesia \\ Jl. Kapas No. 9, Kec. Umbulharjo, Kota Yogyakarta, 55166, Indonesia \\ CorrespondingE-mail: rika.astari@bsa.uad.ac.id
}

\begin{abstract}
This study aims to compare two translations of the Quran, which were known for the first time among Indonesian Muslims around 1930-1950. De Heilig Qoeran, translated into the Dutch language written by Soedewo and Terjemah Quran Karim was translated into the Indonesian language written by Mahmud Yunus. The material object of this study was: De Heilig Qoeran, which was translated Quran into Dutch language, written by Soedewo and Terjemah Quran Karim was translated Quran into Indonesian language written by Mahmud Yunus. The formal object was the difference between these two translations lies not only in the differentiation of language but also the differences in lexical choices given by the two translators in certain verses in their book of translation. This research belongs to a descriptive qualitative. Data were analyzed using the matching method (metode padan). The difference in its meaning was analyzed by lexical decomposition. The results of this study indicate that the lexical choice differences in the two translated books produce significant differences in meaning over the entire verse. De Heilig Qoeran tends to choose lexicon, which has logical meanings while the Tafsir Quran Karim emphasizes supernatural things, especially related to the miracles of the prophets.
\end{abstract}

Keywords: De Heilig Qoeran, lexical choices, miracles of the prophets, semantic analysis

\section{Introduction}

As it is generally known, translated work is one of the communication tools that remove boundaries between two different languages. Target texts tend to use toned down vocabulary compared with their sources. The results in the creating of a sanitized version of the original $1^{1}$. The translator's main aim of bringing the original message over to the target language receptor. Translators are required to have cultural

${ }^{1}$ Dorothy Kenny, "Creatures of habit? What translators usually do with words," Meta: journal des traducteurs/Meta: Translators' Journal, Vol. 43, No. 4, 1998, 515-23. 
knowledge and are expected to use this knowledge for linguistic mediation ${ }^{2}$. Understanding a message means interpreting it based on the required background knowledge. The translator renders into another language what words in the original news mean in their culture. If such experience is missing due to cultural differences, it should be supplied or compensated for ${ }^{3}$, or additional information that explains facts and ideas that are not known by the receptors ${ }^{4}$.

To achieve the best level of understanding of both linguistic codes, the source language (SL) and the target language (TL), a process called semantic must be done. Semantic process failure will cause problems in transferring the intended meaning from one language to another. Research conducted by Balla and Siddiek ${ }^{5}$ stated that lexical-semantic is one of the important branches of semantic linguistic, namely the study of the meaning of words and how they are related to one another concerning the meanings attached to each of those words.

The initial step in the translation process is the analysis of the target language, so there is no error in understanding the content or the message being translated ${ }^{6}$.

In each translation process, the manuscript in the target language must contain the key elements of the source language script. The effects of the two texts can be felt the same by the reader. The key ingredients include lexical, grammatical, and stylistic choices into TL according to the translator's understanding of the original text in SL. Translation competence by the source text is quite fair organized with comprehending of the content sufficiently yet; there is still mistake on diction, grammar, punctuation and word selection influencing the quality of the translated target text ${ }^{7}$. Specific shifts can affect the reception of texts ${ }^{8}$. Then, what about the translation of the Quran?

Unlike other texts, the Quran has many things that make it difficult to translate, both from internal and external factors. Arabic Grammar of the Quran has some patterns, changes in movements (harakat) caused by position differences in i'rab,

\footnotetext{
${ }^{2}$ Caiwen Wang, "Interpreters: Cultural Mediators", translatologia: a journal of translation, Language and Literature, Vol. 1, 2017, 93.

3 Vilen N. Komissarov, "Language and Culture in Translation: Competitors or Collaborators", traduction, terminologie, redaction, Vol. 4, No. 1, 1991, 43. 43.

4 Vilen N. Komissarov, "Language and Culture in Translation: Competitors or Collaborators",

${ }^{5}$ Asjad Balla and Ahmed Gumaa Siddiek, "Complications of Translating the Meanings of the Holy Qur'an at Word Level in the English Language in Relation to Frame Semantic Theory", ALLS, Vol. 8, No. 5, 2017, 172-188.

${ }^{6}$ Novia Arifatun, "Kesalahan Penerjemahan Teks Bahasa Indonesia Ke Bahasa Arab Melalui Google Translate (Studi Analisis Sintaksis)", Lisanul'A rab: Journal of Arabic Learning and Teaching, Vol. 1, No. 1, 2012.

7 Hanna Sundari, and Rina Husnaini Febriyanti, "Translation techniques and translation competence in translating informative text for Indonesian EFL learners", Scope: Journal of English Language Teaching, Vol. 1, No. 1, 2017, 17-28.

${ }^{8}$ Joanna Wyszyriska, "ideology in translation: polish literature of world war II in Spanish translation”, translatologia: a journal of translation, Language and Literature, Vol. 1, 2017, 52.
} 
alriyadah pattern which have a lot of ways, as well as placement and the pattern of $i^{\prime} d \bar{a} t$ attartib, especially in taqdim wa ta'khir and hafdr:

Besides, the preposition of Arabic (translation) consists of grammatical categories that cannot be translated into direct lexical. ${ }^{10}$ Research on the translation carried out by Sari and friends concluded that there were no fundamental differences regarding the translation of imperfective and time aspects in surah Alqashash in the translation of the Ministry of Religion of Indonesia and interpretation book Almisbah. Both use similar words to translate the imperfective elements that are related to time in surah Alqashash. But sometimes, the two translations also imply the pointers when translating imperfective aspects. ${ }^{11}$ Yayan stated that based on the analysis of functions, a verse of the Quran which is translated does not necessarily produce a translation that has the same syntactic pattern as the source language.

Translating the Quran into non-Arabic languages was banned in the Islamic world due to fears of bias from the ideology of the translator ${ }^{12}$. Quran has all problematic aspects of a text that can hinder the translation process, there are; specific cultural idioms, content and themes that depend heavily on context, semantic-laden vocabulary, interpretation problems, unprecedented rhetoric, including the presence of rich allegories and alliteration at almost every end of the verse, various religious functions and the culture of the source manuscript, significant historical and sentimental values, to ethical and theological arguments that oppose the attempt to translate it.

The existence of the translation of the Quran is needed by non-Arab Muslims who cannot understand the language of the Quran directly even though they can read it, especially for those who cannot read it at all. This is the main reason for the ongoing translation activities of the Quran, even though it is opposed by many parties $^{13}$. Referring to research conducted by the Pew Research Center in 2017, at least two-thirds of the world's Muslim population is non-Arab, where Indonesia is the country with the largest Muslim population, around $87.2 \%$ of the total population ${ }^{14}$.

9 Wati Susiawati, "Implementasi Teori Chomsky dalam Bahasa Alquran", Arabiyat: Jurnal Pendidikan Bahasa Arab dan Kebahasaaraban, Vol. 5, No. 2, 2018, 273-91.

10 Muhammad Ibnul Hakim Bin Mohd Saad Luqman dan Marahaini Ahmad, "Ad-Dirasah adDilaliyah fi Tarjamah Huruf al-Jarr al-Arabiyah ila al-lughah al-Maliziyah", Arabiyat: Jurnal Pendidikan Bahasa Arab dan Kebahasaaraban, Vol. 4, No. 2, 2017, 300-320.

${ }^{11}$ Novita Sekar Arum Sari, Mohamad Zaka Al Farisi Syihabuddin, and Mohamad Zaka Al Farisi, "Realisasi Penerjemahan Aspek Imperfektif dalam Alquran Surat Al-Qashash", Arabiyat: Jurnal Pendidikan Bahasa Arab dan Kebahasaaraban, Vol. 5, No. 2, 2018, 255-72.

12 Ahmad Najib Burhani, "Sectarian Translation of the Qur'an in Indonesia: The Case of the Ahmadiyya", Al-Jami'ab: Journal of Islamic Studies, Vol. 53, No. 2, 2015, 251-82.

13 Betty Mauli Rosa Bustam dan Rika Astari, "Meaning Differences Between Two Quran Translation in Activism Era in Indonesia (Ideology in Translation Analysis)", Journal Analisa, Vol. 03, 2018, 131.

14 Drew Desilver dan David Masci, "World's Muslim Population More Widespread Than You Might Think", Pew Research Center, 2017, https://www.pewresearch.org/fact-tank/2017/01/31/worldsmuslim-population-more-widespread-than-you-might-think/. 
However, the translation of the Quran as a complex process cannot be separated from its three main components; the scholars, linguists, and translators of the Quran. As mentioned above, linguistic factors in a translation are in the form of lexical, grammatical, and stylistic differences. These differences usually produce translation challenges that are difficult for translators to decide. The socio-cultural factor reflects the contrast between the socio-cultural background of the SL scriptwriter and the translator as the TL manuscript maker. This socio-cultural difference usually has an unconscious effect on humans as readers and writers. In other words, humans are a product of their socio-cultural environment and so are the texts of SL and TL. All the differences mentioned above are important factors that can have a significant impact on the lexical, grammatical, and stylistic choices made by the translator ${ }^{15}$. As an example of the Quran which was translated into Sundanese, transculturation in translation of pronouns in the translation of the Quran in the Sundanese language occurred, the translation of the Quran into Sundanese has not been able to fulfill the gender aspect because Sundanese language has no morphological markers of gender, except explicit linguistic devices ${ }^{16}$. However, the Quran is not an ordinary script as a text that is often found in everyday life, the Quran carries diverse and dynamic meanings and functions, even though by chance, it is linguistically actualized. Indeed, SL of the Quran in Arabic, but its function as the Scripture that it makes it not just an ordinary script and the process of translating it becomes a complicated matter.

This research seeks to compare two translations of the Quran which were known for the first time among Indonesian Muslims around 1930-1950. De Heilig Qoeran, which is a translation of the Dutch-language Quran by Soedewo and Terjemah Quran Karim by Mahmud Yunus, two Indonesian Muslim intellectuals at that time. The difference between these two translations lies not only in the differentiation of language but also the differences in lexical choices given by the two translators in certain verses in their book of translation. Lexical differences have implications for the difference in the meaning of the verse as a whole. Therefore, the problems that arise due to differences in lexical choices in the two translation books mentioned above are considered essential for semantic analysis.

\section{Method}

This was a descriptive qualitative study that analyzed data inductively. The material object of this study was: De Heilig Qoeran, which is translated Quran into Dutch language written by Soedewo and Terjemah Quran Karim is translated Quran into Indonesian language written by Mahmud Yunus. The formal object was the difference between these two translations lies not only in the difference of language,

${ }^{15}$ Jamal Mohamed Giaber, "Implications of Lexical Choices in Translating Novels as Literary Texts", Journal of Translation and Technical Communication Research, Vol. 8, No. 2, 2015, 416.

16 Syihabuddin, "Transkulturasi Dalam Penerjemahan Pronomina Pada Terjemahan Alquran Bahasa Sunda", Arabiyat: Jurnal Pendidikan Bahasa Arab dan Kebahasaaraban, Vol. 5, No. 1, 2018, 1-14. 
but also the differences in lexical choices given by the two translators in certain verses in their book of translation.

The provision of data began with data collection, namely Arabic vocabularies that experience different conceptual meanings in the Dutch Translation of the Qur'an and the Indonesian Translation of the Qur'an. The data collection was done by the method of listening (simak method). The technique used is the note-taking technique. Then the data is verified with a Dutch-Indonesian dictionary. Data were analyzed using the matching method. Comparative techniques are used to compare the elements of word meanings found in Dutch and Indonesian.

\section{Result and Discussion}

Changes in the Formation of Dutch Words

There are several important points as fundamental differences in the translation of the two books, namely:

1. Differences in language groups between Arabic, Dutch and Indonesian

2. The difference in lexical concepts causes the difference in giving a translation equivalent.

3. Dutch includes the Indo-European family, while Indonesian consists of the Austronesian family and Arabic consists of the Semitic-Hemite family.

As in Indonesian, Dutch also experienced changes in word-formation. In the twentieth century, the spelling of the Dutch language underwent several changes. Prominent differences in new spelling compared to old spellings ${ }^{17}$ are:

1. - sch at the end of the word becomes $-\mathrm{s}$, for example:

\begin{tabular}{|c|c|}
\hline old spelling & new spelling \\
\hline Mensch & Mens \\
\hline Visch & Vis \\
\hline Versch & Vers \\
\hline
\end{tabular}

2. The derivative form of the word, such as plural, verbal form, and comparative form:

\begin{tabular}{|l|l|}
\hline old spelling & new spelling \\
\hline Menschen & Mensen \\
\hline Visschen & Vissen \\
\hline
\end{tabular}

3. The Form of article den becomes de except in a number of fixed expressions

17 Susi Moeimam and Hein Steinhauer, Kamus Belanda-Indonesia, 1 Jakarta: Gramedia Pustaka Utama, 2014). 
Ara6iyât Jurnal Pendidikan Bahasa Arab dan Kebahasaaraban, 6 (2), 2019

4. Use a connecting line between certain vowels to replace the trema sign, for example: zeeegel becomes zee-egel

5. Use the plural form -en as the first element of the noun compound word, for example: apestaart becomes apenstaart

For example:

\begin{tabular}{|c|c|}
\hline old vocabulary & new vocabulary \\
\hline Hebban & Hebben \\
\hline Olla & Alle \\
\hline Vogala & Vogels \\
\hline Nestas & Nesten \\
\hline Bigunnan & Begonnen \\
\hline
\end{tabular}

The changes in the form of the word above, are found in the translation of the Quran of the Dutch version, De Heilig Qoeran, which was the object of this research. This is because the book was published in the early 1930s and still uses the old spelling. These changes in word format made researchers challenging to search for some vocabulary meanings in the Dutch language dictionary because the word had changed shape. However, this can be overcome by reproducing references related to this form change.

\section{Lexical Choices of Two Book Quran Translations in Translating Prophetic Verses}

Here are some verses in two book Quran translations with different lexical choices between the Dutch version, De Heilig Qoeran, by Soedewo and Indonesian version, Tafsir Quran Karim, by Mahmud Yunus. This lexical choice difference affects the differences in lexical meanings and contextual meanings in the two translated books, thus leading to differences in the meaning of the verse as a whole.

1. Differences in lexical choices in translating the word امرأة in Q.S. Ali Imran: 35.

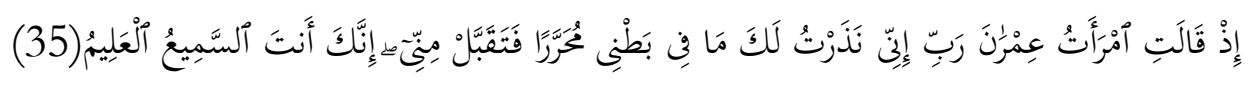

The word أمرأة in the al-Ma'ān̄i dictionary has the meaning: wife, woman. In Arabic, to indicate a wife, there are words: امرأة, زَوْجَةٌ, حَرِيهِ while to show women, namely

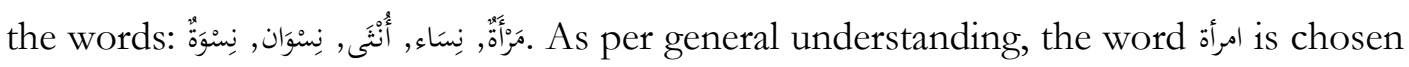
for Q.S. Ali Imran: 35 which describes the desires of women in general, who have good offspring, children who are pious.

The word امرأة in Dutch is often translated as vrouw, which means: woman. In Dutch, things related to women, followed by the word vrouw, both from the tools used by women (ex: bidsluier voor vrouwen: Muslim woman's prayer cloth or sluier voor vrouw: 
Ara6iyât Jurnal Pendidikan Bahasa Arab dan Kebahasaaraban, 6 (2), 2019

veil), organs that show women, things the presents of woman (sexy voor vrounen: voluptuous), the profession of women (huisvrouw: housewife, koopvroum: basket), even female ghosts (vrouwelijk spook). The daily use of the word vrouw are as follow ${ }^{18}$ :

- een vrouw van lichte zeden: prostitute

- er zijn meer vrouwen dan mannen: women more than men

- vanaf nu zijn jullie man en vrouw: fromnow on you are husband and wife

Whereas to indicate the wife in Dutch, use the word echtgenote, wijf / wijven and to indicate the husband used the word: echtgenoot, the example of these words in the sentence ${ }^{19}$ as follow:

- zij gingen zonder hun echtgenotes naar het feest: they leave without their wives

- ie mand tot echtgenote nemen: marry someoner

- de langstevendeechtgenoot. The longest-lived member of a married couple

Translation of Q.S. Ali Imran (3): 35 of De Heilig Qoeran version as follows:

Toen een vrouw van Amran zei: Mijn Heer! Waarlijk, U wijd ik wat in mijn baarmoeder is, om (aan Uw dienst) te worden opgedragen; neem derbalve van mij aan; waarlijk, Gij rijt de Hoorende, de Wetende

Translation of Q.S. Ali Imran (3): 35 of Tafsir Quran Karim version as follows:

(Ingatlab) ketika isteri Imran (Hannab) berkata; Ya Tubanku, sesunggubnya aku nazarkan anak di dalam kandunganku kepadaMu; (jika dia lelaki) untuk dimerdekakan (menjadi khadam Baitul Maqdis), sebab itu terimalab dia daripadaku, sesunggubnya Engkau Maha Mendengar lagi Maha Mengetahui.

Based on the explanation of the lexical choices above, the word أمرأة if translated into Dutch with een vrouw, then experiences a shift in meaning from its source language, Arabic. In Dutch translation, the word vroum is translated as a woman. Here can be seen from the previous word followed by the word een which indicates the unit of an object or something. If followed by nouns, translated with: 'a' or 'an'. In De Heilig Qoeran, een is followed by the word vrouw, so it is translated as a person (een vrouw van Amran) which means one of the women from the family of Imran. Here it is not stated clearly that the woman in question is Imran's wife, although it can also be interpreted as a wife. However, in Dutch, the word vrouw can mean a woman or wife. The choice of the word vroum by Soedewo, if it is associated as sociocultural, the assumption arises that in Dutch culture a husband may only have one wife, as the phenomenon in their society.

In the translation of Tafsir Quran Karim, Mahmud Yunus explicitly states that the woman referred to in this verse is Imran's wife, even he wrote her name, Hannah,

18 Susi Moeimam dan Hein Steinhauer, Kamus Belanda-Indonesia, Jakarta: Gramedia Pustaka Utama, 2014), 1177.

${ }^{19}$ Susi Moeimam dan Hein Steinhauer, Kamus Belanda-Indonesia, 271. 
Ara6iyât Jurnal Pendidikan Bahasa Arab dan Kebahasaaraban, 6 (2), 2019

and placed in the bracket as explanatory. This indicates that Mahmud Yunus was very sure of what he meant in the translation.

2. Differences in lexical choices in translating the word رَفَعَُ اللهُ in QS. An-Nisa' (4) : 158

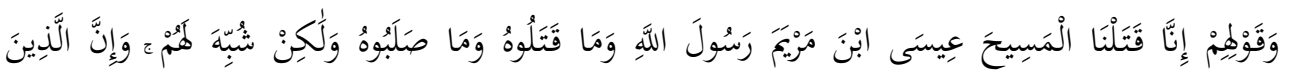

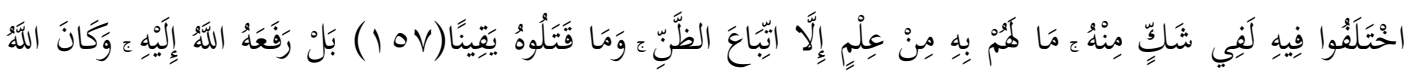

عَزيزًا حَكِيمًا (101)

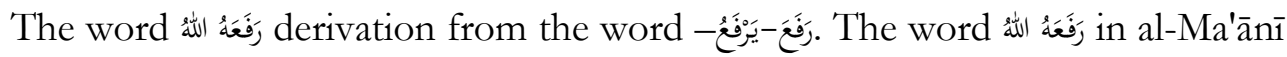
dictionary has the meaning: elimination, ending, lift(ing), putting an end to, raising, removal, taking away; while to show the word glorification is used the word: احترم-يحترم,

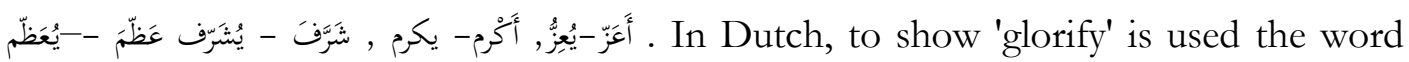
verbief, verheerlijken and the lexicon that shows the meaning of lifting: verhogen.

The following is a lexicon in Dutch that shows the meaning of 'lift'.

\begin{tabular}{|c|c|c|c|}
\hline word & meaning & $\begin{array}{c}\text { example in } \\
\text { sentence }\end{array}$ & meaning \\
\hline \multirow[t]{2}{*}{ opheffen } & \multirow{2}{*}{$\begin{array}{l}\text { lifting } \\
\text { objects or } \\
\text { figures of } \\
\text { speech }\end{array}$} & een partij opheffen & $\begin{array}{l}\text { lifting } \\
\text { luggage }\end{array}$ \\
\hline & & het hoofd opheffen & $\begin{array}{l}\text { raise his } \\
\text { head }\end{array}$ \\
\hline tillen & $\begin{array}{l}\text { lift up, } \\
\text { assume }\end{array}$ & & \\
\hline optillen & $\begin{array}{l}\text { lifting } \\
\text { objects }\end{array}$ & $\begin{array}{l}\text { bij tilde in z'n eentje } \\
\text { de zware koffer op }\end{array}$ & $\begin{array}{l}\text { he lifted } \\
\text { the heavy } \\
\text { suitcase } \\
\text { alone }\end{array}$ \\
\hline \multirow[t]{3}{*}{ stijgen } & go up & het pad stijgt & $\begin{array}{l}\text { the trail } \\
\text { goes up }\end{array}$ \\
\hline & \multirow[t]{2}{*}{$\begin{array}{l}\text { rise/increas } \\
\mathrm{e}\end{array}$} & hij stijgt in rang & $\begin{array}{l}\text { the price / } \\
\text { temperatur } \\
\text { e rises }\end{array}$ \\
\hline & & de kwaliteit stijgt & $\begin{array}{l}\text { quality } \\
\text { increases }\end{array}$ \\
\hline $\begin{array}{l}\text { het } \\
\text { oplichten }\end{array}$ & $\begin{array}{l}\text { cheat, lift } \\
\text { up }\end{array}$ & $\begin{array}{l}\text { het deksel van de } \\
\text { kist oplichten }\end{array}$ & $\begin{array}{l}\text { lift the lid } \\
\text { of the } \\
\text { chest }\end{array}$ \\
\hline ophijsen & $\begin{array}{l}\text { lift by } \\
\text { hoisting up }\end{array}$ & $\begin{array}{l}\text { ze bezen het anker } \\
\text { op }\end{array}$ & $\begin{array}{l}\text { they } \\
\text { hoisted }\end{array}$ \\
\hline
\end{tabular}


Ara6iyât Jurnal Pendidikan Bahasa Arab dan Kebahasaaraban, 6 (2), 2019

\begin{tabular}{|l|l|l|l|}
\hline & & & $\begin{array}{l}\text { their } \\
\text { anchors up }\end{array}$ \\
\hline verheffen & lift, raise & $\begin{array}{l}\text { iemand tot/in de } \\
\text { adelstand verheffen }\end{array}$ & $\begin{array}{l}\text { lifting, } \\
\text { raising } \\
\text { someone } \\
\text { to be a } \\
\text { noble }\end{array}$ \\
\hline
\end{tabular}

Translation of Q.S. An-Nisa' (4) : 158 De Heilig Qoeran version as follows:

Neen! God verbief hem in Zijn tegenwoordigheid; en God is Machtig, Wijs. No! God raised him in His presence; and God is Mighty, wise

'Translation of Q.S. An-Nisa' (4) : 158 Tafsir Quran Karim version as follows:

Babkan Allab mengangkat Isa itu kepadaNya, dan Allab Maba Perkasa Lagi Maba Bijaksana.

God verbief hem in Zijn tegenwoordigheid, Allah glorifies him (Isa) before Him. Soedewo chose the "verhief" lexicon to translate the word فر which means "elevate or glorify" as described above. The choice of this lexicon means that God glorifies Isa/Jesus by not allowing him to die on the cross and considered damned. Soedewo revealed the reason for choosing the verbief lexicon as follows:

"Razi said in his explanation about Q.S. 3: 54, that is: where rafa' Isa/Jesus is meant here is praise and glorification, not elevating to a place or destination. And indeed, rafa' for humans means increasing degrees, and there is no suitable word to translate except the word used in the Quran or the prophetic hadith with other meanings. As contained in Q.S. Almujaadila: 11".

Based on the explanation above, there is a difference in lexical choices in translating the word in the translation of the Quran in the Dutch language is used as a verbief lexicon which means 'glorify', where the word undergoes a change in shape. If in the modern Dutch dictionary, this word becomes verheffen with the same meaning. Whereas in the Tafsir Quran Karim, Mahmud Yunus chose the lexicon 'raised' with its true meaning. The researchers assume that Mahmud Yunus was influenced socioculturally that the majority of the Indonesian Muslim community believed that Prophet Isa was lifted by his soul and body by Allah before Him and remained there until near the end of the world when Prophet Isa was revealed again by Allah to the world as al-Mahdi. The story about al-Mahdi is believed by most Indonesian Muslims who refer to the Prophet's hadith narrated by Imam Muslim in his hadith book, Juz I on the chapter Nuzulul-Masih ${ }^{20}$ and hadith narrated by Imam Ibn Majah in his book on the chapter Syiddatuz-Zaman ${ }^{21}$.

${ }^{20}$ Imam Muslim Al-Hajjaj, Sabih Muslim, (Riyadh: Darus-Salam Lin-Nasyri wat-Tawzi', 2007).

${ }^{21}$ Ibnu Majah bin Abdillah, Sunan Ibn Majah, (Beirut: Darul-Ihya' al-Arabiyah, 1984). 
Arabiyât Jurnal Pendidikan Bahasa Arab dan Kebahasaaraban, 6 (2), 2019

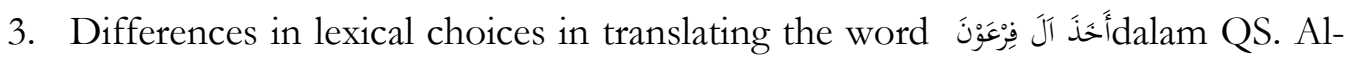
A'raf (7): 130 .

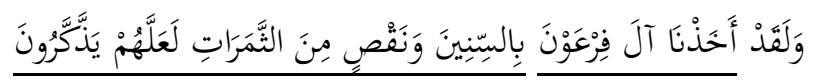

The word ${ }^{\top} T$ in al-Ma'ānī dictionary has the meaning: family, house, kin, kindred, kinsfolk, people, relatives. In Arabic, to indicate the meaning 'family' can be used words: أسرة, أقارب, أقربون, أقرباء, آل, أهل , while in Dutch for family term meaning using the word: 'de familie'. Based on the Dutch dictionary ${ }^{22}$, to indicate 'followers' term meaning, used the word volgeling. Example in sentence: een troune volgeling: faithful followers, while volk means: person, nation or people. If what is meant is the Pharaoh's family, then it may be translated as 'de familie van de Farao'. The daily use of word volk as follows:

- er was veel volk op de been: there are lots of people on the street

- het nederlandse volk staat bekend om rijn zuiningheid: the people of the Netherlands are known for their economics

The differences of translation Q.S. Al-A'raf (7): 130.

Translation of De Heilig Qoeran version as follows:

En zekerlijk grepen Wij Faraös volk aan met droogten en vermindering van vrucbten, opdat zij gedachtig zullen zijn

Translation of Tafsir Quran Karim version as follows:

Dan sesunggubnya telah Kami seksa keluarga Firaun dengan musim kemarau dan kekurangan buah-buahan, mudah-mudahan mereka mendapat peringatan.

In the De Heilig Qoeran word Tرع is translated as 'the people of Pharaoh (followers)', because Pharaoh was a king of a powerful regime, so it is usual that he had people around him who were loyal. The use of the word $J i$ can be translated as 'follower / folk' because the followers/folk are very faithful to Pharaoh by considering him as a god. Whereas in the Tafsir Quran Karim, the lexicon chosen to translate the word $J i$ is family. Usually, families are not only connected by the proximity but also caused by blood ties. However, the threat of disaster inflicted by God in the form of a dry season and lack of fruit, can be ascertained not only by Pharaoh and his family, but also by all his people (followers), because the disaster in general and cannot be localized at at specific place, for example, the King's palace.

4. Differences in lexical choices in translating the word الطُوْفَن in Q.S. Al-A'raf (7): 133.

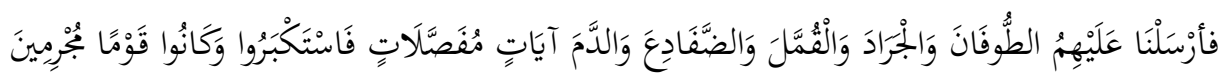

The differences of translation Q.S. Al-A'raf (7): 133 as follow:

${ }^{22}$ Susi Moeimam dan Hein Steinhauer, Kamus Belanda-Indonesia, 1156. 
Arabiyât Jurnal Pendidikan Bahasa Arab dan Kebahasaaraban, 6 (2), 2019

Translation of De Heilig Qoeran Version

Derhalve zonden Wij over hen een wijdverbreiden dood, en de sprinkbanen en de luizen en de vorschen en het bloed, duidelijke teekenen; maar zij gedroegen zich hoovaardiglijk en zij waren een schuldig volk.

Translation of Tafsir Quran Karim version

Kemudian Kami datangkean kepada mereka taufan (bah), belalang, ulat, katak dan darah sebagai ayat-ayat (tanda) yang nyata. Lalu mereka berlaku sombong dan adalah mereka kaum yang berdosa.

The word الطُوْفَانَ comes from the word: طَفَ- يَطُوْفُ chich means 'surround'. However, in the Tafsir Quran Karim, Mahmud Yunus chose the lexicon 'typhoon or flood' to translate it. In Arabic, many lexicons indicated wind other than the typhoon:

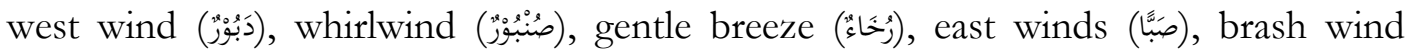

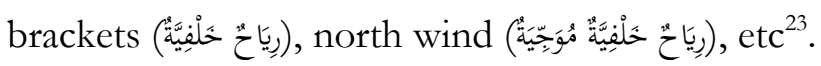

In the De Heilig Qoeran, the word الطُوْفَانَ is translated wijdverbreiden dood (widespread of death), referring to its origin: طاف - which means to surround. This meaning is in accordance with the hadith narrated by Imam Bukhari that is meant by الطُوََْانَ there is a disaster which results in a successive death, so that the impact is widespread and evenly distributed ${ }^{24}$. The word wijdverbreiden means: widespread ${ }^{25}$, while dood means: death, a very bad situation. If the meaning of that word is typhoon or flood as the lexicon used by Mahmud Yunus, then in Dutch is translated as 'overstroming', 'overstromingen'. The use of this word in the sentence is as follows:

\begin{tabular}{|l|l|l|l|}
\hline \multicolumn{1}{|c|}{ word } & meaning & \multicolumn{1}{|c|}{ example of sentence } & \multicolumn{1}{|c|}{ Meaning } \\
\hline $\begin{array}{l}\text { overstromen, } \\
\text { overstroomde }\end{array}$ & flooded & $\begin{array}{l}\text { de rivier overstroomde de } \\
\text { weilanden }\end{array}$ & $\begin{array}{l}\text { the river } \\
\text { flooded the } \\
\text { meadows }\end{array}$ \\
\hline $\begin{array}{l}\text { overstroming, } \\
\text { overstromingen }\end{array}$ & flood & $\begin{array}{l}\text { een grote / qware } \\
\text { overstroming }\end{array}$ & $\begin{array}{l}\text { a large/heavy } \\
\text { flood }\end{array}$ \\
\hline
\end{tabular}

As explained by the author, in De Heilig Qoeran, it is written that, "The Bible mentions the overall death signs are: (1) water turns to blood; (2) forward; (3) fleas; (4) pests; (5) epidemics among livestock and among humans; (6) hail; (7) grasshoppers; (8) darkness; (9) the killing of a newborn baby ${ }^{26}$. Therefore, the translator does not specifically choose the lexicon 'hurricane', 'bah', and to translate word الطُوَْفَان, but

23 A. Thoha Husein Almujahid and A. Atho'illah Fathoni Alkhalil, Kamus Akbar Babasa Arab, (Jakarta: Gema Insani, 2013).

${ }^{24}$ Betty Mauli Rosa Bustam dan Rika Astari, "Meaning Differences Between Two Quran Translations in Activism Era in Indonesia (Ideology in Translation Analysis)", 139.

${ }^{25}$ Susi Moeimam dan Hein Steinhauer, Kamus Belanda-Indonesia, 1216.

${ }^{26}$ Soedewo, De Heilig Qoeran, (Batavia: Derde Druk, 1924). 
returns the word to the original word meaning. Whereas Mahmud Yunus clearly chose the lexicon 'typhoon (flood)', the researchers assumed due to the sociocultural influence in which the Indonesian community had known the word 'typhoon' and could imagine it as a catastrophic impact.

5. The Differences of lexical choices in translating word قِبْلَة in Q.S. Yunus (10) : 87.

$$
\text { الُْوَِْْْنِينَ }
$$

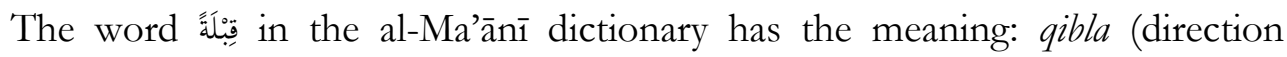
which Muslims turn to in prayers). In Dutch, the word قِبْلَة is translated as bedeplaatsen, which means 'place of worship', because in the Dutch sociocultural does not recognize the concept of qibla and prayer, so if they want to use the qibla word as recognized in Islamic Teachings, they use word qibla directly without translating. Prayer is translated as 'gebed'; the meaning is as same as other forms of prayer, while praying is translated as 'bidden'. The use of these words in Dutch are as follows:

\begin{tabular}{|l|l|l|l|}
\hline word & meaning & $\begin{array}{l}\text { example in } \\
\text { sentence }\end{array}$ & Meaning \\
\hline huis & house & een eigen huis & $\begin{array}{l}\text { private } \\
\text { house }\end{array}$ \\
\hline huizen & live & $\begin{array}{l}\text { we huizen met } \\
\text { z'n zessen in } \\
\text { een } \\
\text { appartement }\end{array}$ & $\begin{array}{l}\text { we live } \\
\text { with six } \\
\text { persons in } \\
\text { one } \\
\text { apartment }\end{array}$ \\
\hline gebed & praying, \\
(337) & prayer & $\begin{array}{l}\text { een gebedje } \\
\text { doen }\end{array}$ & Praying \\
\cline { 3 - 4 } & & $\begin{array}{l}\text { voorgaan in } \\
\text { gebed }\end{array}$ & $\begin{array}{l}\text { lead a } \\
\text { prayer }\end{array}$ \\
\hline
\end{tabular}

The differences of translation Q.S. Yunus (10): 87 as follow:

Translation of De Heilig Qoeran version

En Wij openbaarden tot Mozes en zijn broeder, zeggende: Neem voor uw volk buizen om in Egypte te wonen en maak uw huizen tot bedeplaatsen en onderhoud het gebedaewf, en geef den geloovigen blijde tijdingen 
Arabiyât Jurnal Pendidikan Bahasa Arab dan Kebahasaaraban, 6 (2), 2019

Translation of Tafsir Quran Karim version

Dan telah Kami wahyukan kepada Musa dan saudaranya: Hendaklah kamu ambil beberapa buah rumah di Mesir, untuk. kaummu dan hendaklah kamu jadikan rumah itu sebagai kiblat (tempat sembahyang) dan dirikanlah sembahyang, serta berilah khabar gembira kepada orang-orang yang beriman

The lexicon choice of the De Heilig Qoeran to translate word qibla in verse above is the bedeplaatsen with the same intention in the translation of Tafsir Quran Karim; 'place of worship'. The word sọ translated here as a place of worship, not occur to distortion of meaning, because after the word worship there is an order of prayer, and the Shari'a of prayer is obliged to face the Qibla.

The lexical difference between two translation books be found in the explanation contained in verse. De Heilig Qoeran translates بيوت as 'all houses' occupied by the Israelites, this makes every Israelite able to worship in their own home, this translation is based on the assumption that Egypt is not a safe place for them to worship outside the home. The Israelites of the followers of Prophet Moses were a minority who were always chased by the Pharaoh's army. Whereas Tafsir Quran Karim translates the word بيوت as 'several houses' which is intended to be a special place to carry out prayers for the Israelites like the mosques we know today. The researchers' assumption, Mahmud Yunus's lexical choice in 'several houses' is due to

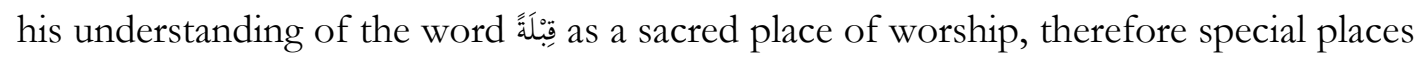
must be determined, not all houses, but houses that have been chosen and agreed upon.

6. The Differences of lexical choices in translating the word (27): 18 .

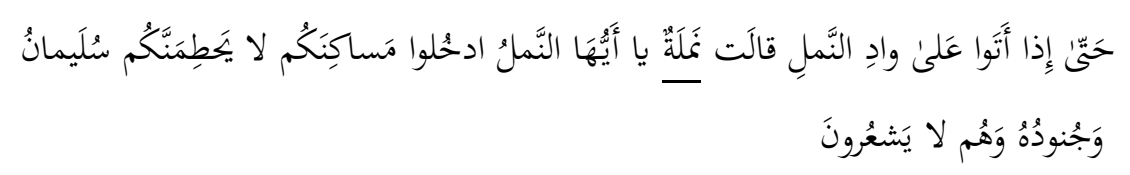

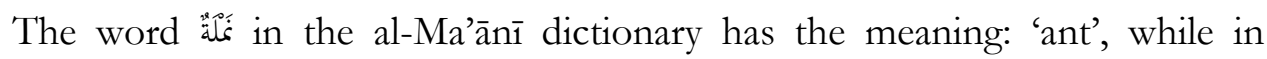
Dutch to indicate ant is used the word 'mier' and to indicate the king of ants: koning van mieren. Following is the use of the word mier in Dutch:

- de rode/zwarte mier: red/black ant

The differences of translation Q.S. An-Naml (27): 18 as follow:

Translation of De Heilig Qoeran version

Tot, toen zij tot de vallei van den Naml kwamen, een Namliet zei: O Naml! ga in un buizen, (opdat) Sallomo en zijn legers u niet zullen verpletteren, terwijl rij (het) niet weten.

Translation of Tafsir Quran Karim version 
Arabiyât Jurnal Pendidikan Bahasa Arab dan Kebahasaaraban, 6 (2), 2019

Sebingga apabila mereka sampai ke lembah semut, lalu berkata raja semut: Wabai sekalian semut, masuklah kamu ke dalam rumahmu supaya kamu tidak dihancurkan oleh Sulaiman dan tentaranya, sedang mereka tidak sadar (terhadapmu)

De Heilig Qoeran tends to use a scientific and rational approach, so it is not fixed on textual meanings. In the scientific/legal context of positive science, it is impossible for an animal to have the ability to speak in human language, so that 'Namlah' is not intended by ants as contained in the interpretations that have known so far. Wad-in-naml is translated as the valley of the ants between Jibrin and 'Asqalan, because wad-in-naml is the name of a valley, therefore logically iَ iَمْهُ tribe occupying the valley, as explained in De Heilig Qoeran as follows:

"Vert-Naml Wad-in is the right name and according to (following) Tadj-ulArus $^{27}$, wad-i naml is located between Jibrin and 'Asqalan. And Namla is the name of a tribe, also Mazin, which literally means: Abriqa is one of the Namla's waters, (the book) says clearly, that Namla is a tribe" ${ }^{28}$.

The Tafsir Quran Karim followed the earlier translated books/interpretations which generally mention that Namla is the name of a valley inhabited by an ant group, the ant group has a leader, an ant king. When Prophet Sulaiman and his army would cross their area, the ant king ordered all members of his group to return home before being trampled by the the military. Whereas De Heilig Qoeran does not clearly state whether one of the tribe members of Namla referred to in verse above is a tribal chief or an ordinary community.

The difference of lexical choices in translating the word Namla in this verse causes a significant difference in understanding the verse as a whole. De Heilig Qoeran still consistently follows the logic that what is meant in the verse is humans whose words can be understood by Prophet Solomon, while the Tafsir Quran Karm underlines the miracle of Prophet Solomon who is able to understand the language of animals, in this case ants.

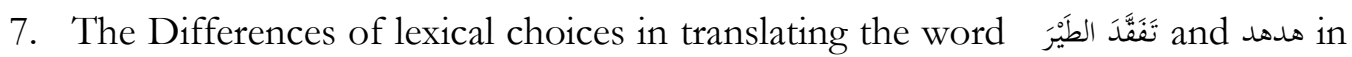
Q.S. An-Naml (27) : 20.

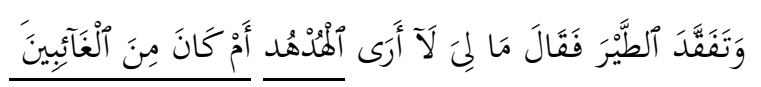

The word هُدْدَ in the al-Ma'ānī dictionary has the meaning: hoopoe bird, while in Dutch to indicate Hud-hud as a bird is used the word 'vogel Hud-hud'.

The differences of translation Q.S. An-Naml (27): 20 as follow:

Translation of De Heilig Qoeran version

En bij nam de vogelen in oogenschoun en zei: Hoe kom het, dat ik Hoedhoed niet rie, of is bij onder de a bfwezigen?

${ }^{27}$ What's meant here is the book titled Tajul-'Arus al-Hawi li Tabdribun-Nufus by Ibn 'Athaillah, Egyptian cleric born in Alexandria in 1260.

28 Soedewo, De Heilig Qoeran, 679. 
Arabiyât Jurnal Pendidikan Bahasa Arab dan Kebahasaaraban, 6 (2), 2019

Translation of Tafsir Quran Karim version

Dan kemudian Sulaiman memeriksa burung-burung, lalu dia berkata: mengapa aku tidak melibat burung Hud-bud atan ia ghaib?

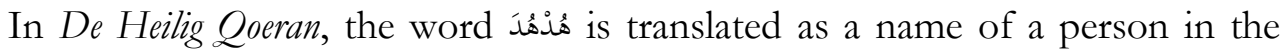
cavalry army; this is considered as a normal because it was generally named someone with an animal name at that time, as explained below:

"The word هُ ُْهُ does not have to be understood as a bird's name, but someone's name. Usually, that Arabic writer speaks of a king and mention (an animal name like this). This shows that it is not strange that such a name is given to a man. " This explanation is confirmed by another statement, "It is clear that Solomon spoke to one of his officers; that a king who was as strong as Solomon, could not threaten, scold and would impose a severe sentence on a small bird ${ }^{29}$.

Based on the explanation of De Heilig Qoeran above, then the word translated as the name of one of the forces of Prophet Solomon. This is in line with the translator's logic that it is impossible for a King to scold a small bird. Troops led by Prophet Solomon were very obedient troops and subjected to obey the King's orders. Every soldier traveling or doing work should get permission from him first. If anyone violates this provision, he will get a sentence from Solomon.

In the Tafsir Quran Karim, the word هُ هُدْ referred to is the Hud-hud bird as written in the book. This refers to the sentence at the beginning of the verse which translates that Prophet Solomon examined the group of birds while De Heilig Qoeran translated it as a cavalry group as one of the military wings belonging to the kingdom of Prophet Solomon.

8. The Differences of lexical choices in translating the word عفريت in Q.S. AnNaml (27) : 39.

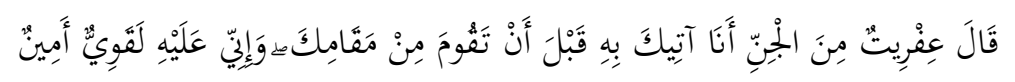

In Arabic, a number of terms are used to indicate supernatural beings, namely

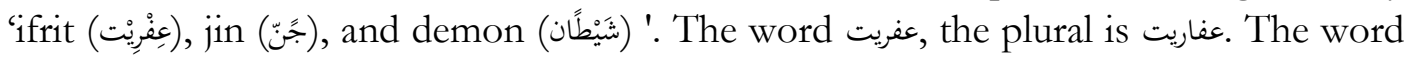
in the al-Ma'ani dictionary has the meaning: 'jinn, devil', whereas in Dutch to indicate jinn is used the word geest which means 'ghost'.

The differences of translation Q.S. An-Naml (27) : 39 as follow:

Translation of De Heilig Qoeran version

Een vermetele onder de djinn zei: Ik zal u dien brengen, aleer gij van uw plaats opstaats; en waarlijk, ik heb er de macht toe (en) ik been betrounbaar

Translation of Tafsir Quran Karim version

${ }^{29}$ Soedewo, De Heilig Qoeran, 680. 
Ara6iyât Jurnal Pendidikan Bahasa Arab dan Kebahasaaraban, 6 (2), 2019

Berkata Ifrid (seorang syaitan) di antara jin: saya boleh membawanya kepadamu, sebelum baginda berdiri dari majlis ini, sesunggubnya saya kuat lagi jujur

In the De Heilig Qoeran, the word عفريت here is translated as 'someone brave' (vermetele), because he can move the throne in a transient. A brave person in question was from an army that belonged to the kingdom of Prophet Solomon. This reinforces the assumption that De Heilig Qoeran tends to avoid the choice of a lexicon that shows the miraculous features of a Prophet and believes that the Quran often uses terms commonly known in the era of the Prophets described therein. This is different from Tafsir Quran Karim that called it the name of a demon from the Jin group. Starting from De Heilig Qoeran, the Tafsir Quran Karim is trying to highlight every miracle that is owned by the Prophets, adjusting stories that are already known in the Islamic community, including in Indonesia.

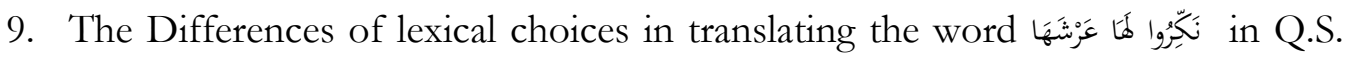
An-Naml (27): 41.

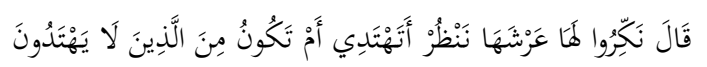

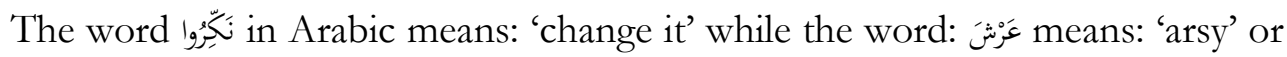
'throne', whereas in Dutch to indicate 'arsy or throne' is used the word troon. Here, there is no difference in the use of words in both languages to indicate the meaning of arsy as throne. The use of the word troon in Dutch is as follows:

\begin{tabular}{|l|l|l|l|}
\hline word & meaning & example in sentence & meaning \\
\hline \multirow{2}{*}{ veranderen } & change & van meaning veranderen & $\begin{array}{l}\text { change of } \\
\text { opinion }\end{array}$ \\
\hline \multirow{2}{*}{ troon } & throne & $\begin{array}{l}\text { op de troon zitten } \\
\text { power }\end{array}$ & $\begin{array}{l}\text { occupy the } \\
\text { throne }\end{array}$ \\
\cline { 2 - 5 } & & $\begin{array}{l}\text { afstand doen van de } \\
\text { troon }\end{array}$ & $\begin{array}{l}\text { down let go of } \\
\text { his throne }\end{array}$ \\
\cline { 2 - 5 } & god van zijn troon & pray solemnly \\
\hline
\end{tabular}

The differences of translation Q.S. An-Naml (27) : 41 as follow:

Translation of De Heilig Qoeran version

Hij zei: Verander haar troon voor haar; wij zullen zien, of zij den rechten weg volgt, of dat zij (een) van degenen is, die niet recht geleid zijn

Translation of Tafsir Quran Karim version

Ubablah bentuk takhta kerajaan itu, nanti kita lihat dapatkah dia mengetabuinya atau tidak mengetahuinya 
Arabiyât Jurnal Pendidikan Bahasa Arab dan Kebahasaaraban, 6 (2), 2019

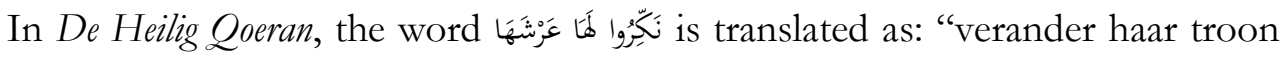
voor haar": change her throne for her. Further explained by the translator that the purpose of changing the throne was to replace the Queen's throne with images of idol worship so that Solomon and his people could see whether the Queen chooses the right path or vice versa. This is different from the translation made by Mahmud Yunus, namely "change the shape of the throne of the kingdom; we will see later whether she knows it or does not know it." This is intended to find out whether the Queen knows the throne of the kingdom (throne) or not after being changed on the orders of Prophet Solomon.

The De Heilig Qoeran translator gives further explanation as follows:

Perhaps the throne was decorated with immoral images or idolatry statues, and Solomon ordered to eliminate them ${ }^{30}$. This translation is more appropriate with the logic of changing the symbol of the throne of Queen (Balqis) which is allegedly decorated with idols or some immoral images compared to changing the shape of the throne which certainly cannot be done in a short time.

10. The Differences of lexical choices in translating the word غدو - الجن in Q.S. Saba (34): 12

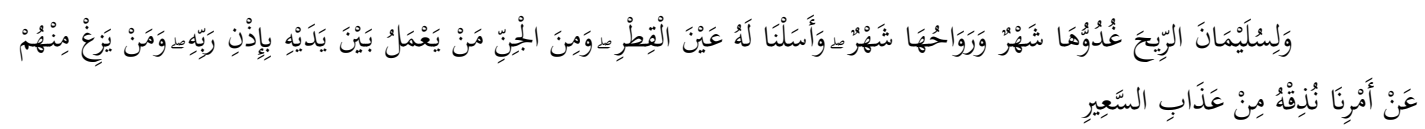

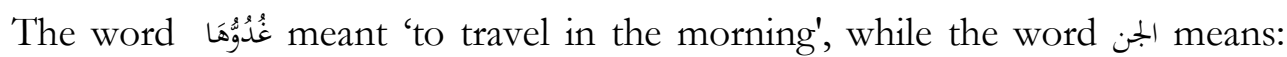
'jinn, devil', in Dutch to indicate jinn used the word geest and to indicate the devil or demon used the word: duivel. The uses of these words in the sentences as follow:

\begin{tabular}{|l|l|l|l|}
\hline word & meaning & $\begin{array}{l}\text { example } \\
\text { in } \\
\text { sentence }\end{array}$ & Meaning \\
\hline duivel & $\begin{array}{l}\text { devil or } \\
\text { demon }\end{array}$ & $\begin{array}{l}\text { ik been } \\
\text { voor de } \\
\text { duivel niet } \\
\text { bang }\end{array}$ & $\begin{array}{l}\text { I am not } \\
\text { afraid of the } \\
\text { devil }\end{array}$ \\
\hline duivel & $\begin{array}{l}\text { devil or } \\
\text { demon }\end{array}$ & $\begin{array}{l}\text { duivel } \text { er } \\
\text { mee spelt }\end{array}$ & $\begin{array}{l}\text { it is as if the } \\
\text { devil is } \\
\text { playing with it }\end{array}$ \\
\hline
\end{tabular}

The differences of translation Q.S. Saba (34): 12 as follow:

Translation of De Heilig Qoeran version

en aan Sàlomo (maakten Wij) den wind (dienstbaar), die een reis van een maand in den ochtend en een reis van een maand in den avond maakte, en Wij deden een overvloed van gesmolten

30 Soedewo, De Heilig Qoeran, 682. 
Arabiyât Jurnal Pendidikan Bahasa Arab dan Kebahasaaraban, 6 (2), 2019

koper voor hem vloeien; en onder de djinn waren er, die voor hem werkten op bevel van zijn Heer; en wie zich uit hun midden van Ons gebod afwendt, hem deden Wij van de kastijding van het branden smaken

Translation of Tafsir Quran Karim version

Dan (kami tundukkan) angin untuk Sulaiman, perjalanan paginya (sama dengan) sebulan perjalanan dan perjalanan petangnya sebulan pula. Kami alirkan baginya mata air (tambangan) tembaga. Di antara jin ada yang bekerja di hadapannya (Sulaiman) dengan izin Tubannya. Barangsiapa yang berpaling di antara mereka dari perintah Kami, Kami rasakan kepadanya siksa api yang menyala-nyala.

In the verse above, De Heilig Qoeran translates with maakten den wind dienstbaar, He (God) makes the wind subservient, which means that with the help of good wind, the ships of Solomon who usually travel for one month can be reached in just one day. But De Heilig Qoeran also mentions that ريح can also mean power, where the vastness of Solomon's (kingdom) power is like traveling a month of travel. Whereas الجن, as previously interpreted, means that the people conquered Solomon, referring to the Book of Chronicles (Kitab Tawarikh).

The wind is interpreted as a natural phenomenon, because with the advancement of shipping technology at the time of Prophet Solomon, by using wind assistance cause the sailboat was faster in the distance. If the word rin is interpreted textually, the translation is a wind. If this word is translated contextually, then the translation is a power. Because the area of the power of Solomon is very wide, if someone wants to surround the area, it takes a month travel. So, Rîh here describes the extent of Solomon's domain.

The translator of De Heilig Qoeran explained as follows: "These genies are none other than foreigners who submit to Solomon to work" ${ }^{31}$. This is referred to as referring to the Book of Chronicles (Kitab Tawarikh) which is commonly known by Christians because it is found in the Old Testament and was written first in Hebrew.

The Tafsir Quran Karim does not give any notes on this verse translation, totally choosing a lexicon that has a balanced meaning with the verse. Therefore, Solomon's morning journey, which is equivalent to a month's trip, is not meant because of the development of shipping technology, but entirely because of God's power.

\section{Conclusion}

Although the Quran is written in Arabic, because of its function as a Scripture, it makes it difficult for translation. Quran contains special things commonly found in a holy book, which cannot be equated with other texts written by humans. The translation of the Quran as a complex process cannot be separated from its three main components; the scholars, linguists, and translators of the Quran. Linguistic factors in translating the Quran become one of the essential elements, which are in the form of

31 Soedewo, De Heilig Qoeran, 773. 
lexical, grammatical and stylistic differences. In this discussion, the linguistic elements which become the focus of the research are lexical differences. Lexical in written text is probably the most marked and has diversity compared to phonology and grammatical. This is because, in a language, vocabulary provides many alternative variations to show the same thing, but some have different meanings.

As mentioned before that the difference of lexical choices can affect the difference in the meaning of the verse as a whole. This is clearly seen from the verses analyzed above. The verses that become an object of this research above are a sample portion of the entire population of lexical choice differences which number more than 50 verses of the entire verse in the Quran. The verses translated differently, caused by the difference of lexical choices, in the two translated books are dominated by verses about Prophethood, especially the verses that tell about the miracles of the prophets.

From the analysis of the entire sample verses, it was found that De Heilig Qoeran prioritized logic by referring to the books of the same principled scholars. Every lexicon chosen that is different from the majority of other commentary books, there is a special statement in De Heilig Qoeran which explains the origin of the reference source. On the contrary, Tafsir Quran Karim actually chose a lexicon that strengthened the assumption of the miracles of the prophets. In several verses, it appears that Tafsir Quran Karim bases its lexical choices on the stories of the prophet which are usually told in classical books and affects the majority of known interpretive books among Muslims.

Although the translation differences of the two books of the Quran translation are significant but do not damage the reader's understanding of the Quran as a whole. In Islam, differences like this enrich the scientific treasury and spark the desire to discuss, especially among intellectuals.]

\section{REFERENCES}

Almujahid, A. Thoha Husein., and A. Atho'illah Fathoni Alkhalil. Kamus Akbar Babasa Arab. Jakarta: Gema Insani, 2013.

Arifatun, Novia. "Kesalahan Penerjemahan Teks Bahasa Indonesia ke Bahasa Arab Melalui Google Translate (Studi Analisis Sintaksis)", Lisanul'Arab: Journal of Arabic Learning and Teaching, Vol. 1, No. 1, 2012.

Balla, Asjad., and Ahmed Gumaa Siddiek. "Complications of Translating the Meanings of the Holy Qur'an at Word Level in the English Language in Relation to Frame Semantic Theory", ALLS, Vol. 8, No. 5, 2017.

Burhani, Ahmad Najib. "Sectarian Translation of the Qur'an in Indonesia: The Case of the Ahmadiyya", Al-Jami'ah: Journal of Islamic Studies, Vol. 53, No. 2, 2015.

Bustam, Betty Mauli Rosa., dan Rika Astari. "Meaning Differences Between Two Quran Translation in Activism Era in Indonesia (Ideology in Translation Analysis)", Journal Analisa, Vol. 3, 2018. 
Ara6iyât Jurnal Pendidikan Bahasa Arab dan Kebahasaaraban, 6 (2), 2019

Desilver, Drew., dan David Masci. "World's Muslim Population More Widespread Than You Might Think", Pew Research Center, 2017. https://www.pewresearch.org/fact-tank/2017/01/31/worlds-muslimpopulation-more-widespread-than-you-might-think/.

Giaber, Jamal Mohamed. "Implications of Lexical Choices in Translating Novels as Literary Texts", Journal of Translation and Technical Communication Research, Vol. 8, No. 2, 2015.

Ibnu Majah. Sunan Ibn Majah. Beirut: Darul-Ihya’ al-Arabiyah, 1984.

Imam Muslim. Sahih Muslim. Riyadh: Darus-Salam Lin-Nasyri wat-Tawzi', 2007.

Kenny, Dorothy. "Creatures of habit? What translators usually do with words", Meta: journal des traducteurs/Meta: Translators' Journal, Vol. 43, No. 4, 1998.

Komissarov, Vilen N. "Language and Culture in Translation: Competitors or Collaborators," traduction, terminologie, redaction, Vol. 4, No. 1, 1991.

Luqman, Muhammad Ibnul Hakim Bin Mohd Saad dan Marahaini Ahmad. "AdDirasah ad-Dilaliyah fi Tarjamah Huruf al-Jarr al-'Arabiyah ila al-Lughah alMaliziyah", Arabiyat: Jurnal Pendidikan Bahasa Arab dan Kebahasaaraban, Vol. 4, No. 2, 2017.

Moeimam, Susi., and Hein Steinhauer. Kamus Belanda-Indonesia. 1. Jakarta: Gramedia Pustaka Utama, 2014.

Sari, Novita Sekar Arum., Mohamad Zaka Al Farisi Syihabuddin, and Mohamad Zaka Al Farisi. "Realisasi Penerjemahan Aspek Imperfektif Dalam Alquran Surat AlQashash", Arabiyat: Jurnal Pendidikan Bahasa Arab dan Kebahasaaraban, Vol. 5, No. 2, 2018.

Soedewo. De Heilig Qoeran. Batavia: Derde Druk, 1924.

Sundari, Hanna., and Rina Husnaini Febriyanti. "Translation techniques and translation competence in translating informative text for indonesian EFL learners", Scope: Journal of English Language Teaching, Vol. 1, No. 1, 2017.

Susiawati, Wati. "Implementasi Teori Chomsky Dalam Bahasa Alquran", Arabiyat: Jurnal Pendidikan Bahasa Arab dan Kebahasaaraban, Vol. 5, No. 2, 2018.

Syihabuddin, Syihabuddin. "Transkulturasi Dalam Penerjemahan Pronomina Pada Terjemahan Alquran Bahasa Sunda", Arabiyat: Jurnal Pendidikan Bahasa Arab dan Kebahasaaraban, Vol. 5, No. 1, 2018.

Wang, Cai Wen. "Interpreters: Cultural Mediators", translatologia: a journal of translation, Language and Literature, Vol. 1, 2017.

Wyszyriska, Joanna. "ideology in translation: polish literature of world war II in Spanish translation", translatologia: a journal of translation, Language and Literature, Vol. 1, 2017. 